\title{
PENERAPAN TEKNOLOGI PRODUKSI BERSIH (CLEANER PRODUCTION) UNTUK PENINGKATAN PRODUKTIVITAS DAN KUALITAS KACANG OVEN PADA AGROINDUSTRI "UD. RAJAWALI" KABUPATEN JEMBER
}

\author{
${ }^{\# 1}$ Dr. Sumadi, SE. MM., ${ }^{\text {"2} I r . ~ D i d i e k ~ H e r m a n u a d i, ~ M T . ~}$ \\ \#Jurusan Manajemen Agrobisnis, Politeknik Negeri Jember \\ Jl. Mastrip Kotak Pos 164, Jember \\ *Jurusan Teknologi Pertanian Politeknik Negeri Jember \\ Jl. Mastrip Kotak Pos 164, Jember \\ ${ }^{1}$ madidhea57@gmail.com
}

\begin{abstract}
Dewasa ini perkembangan Agroindustri kacang oven semakin meningkat, selaras dengan kebutuhan konsumsi kacang di masyarakat yang juga mengalami peningkatan. Agroindustri kacang oven merupakan suatu sub sistem agribisnis yang terkait dengan sub sistem yang lain. Mulai dari sub sistem on farm production, pedangan pengumpul (juragan kacang tanah), sub sistem pemasaran (salesman), dan industry pengemasan dan transportasi. Sub sistem tersebut terintegrasi dalam sustu sistem usaha UD"RAJAWALI" Desa Panti, Kecamatan Panti Kabupaten Jember.
\end{abstract}

Persoalan di lapangan menunjukkan bahwa UKM Mitra mengalami hambatan dalam penyediaan bahan bakar arang kayu yang semakin mahal dan langka sehingga mengganggu kelancaran usaha dan menambah beban biaya produksi. Disamping itu, seiring dengan tuntuntan produksi bersih (cleaner production) maka tuntutan mengkonversi arang kayu ke gas LPG sudah menjadi kebutuhan yang sangat mendesak agar dihasilkan produk yang lebih berkualitas dan aman dikonsumsi serta berdampak negatif terhadap lingkungan.

Melihat prospektif agroindustri kacang oven tersebut di atas, merupakan tantangan tersendiri bagi Politeknik Negeri Jember sebagai institusi pendidikan tinggi untuk ikut serta mengembangkan teknologi prosesing pengolahan serta mempercepat proses diseminasi inovasi teknologi dan perbaikan manajemen usaha guna meningkatkan daya saing dan market share. UD "RAJAWALI “ Desa Panti, Kecamatan Panti, Kabupaten Jember.

Keywords : Kacang Oven, Produktivitas, Teknologi

\section{PENDAHULUAN}

Perkembangan usaha di bidang agroindustri pangan dewasa ini mengalami pertumbuhan yang semakin menggembirakan, hal demikian dikarenakan semakin banyaknya masyarakat yang membutuhan kacang oven yang merupakan salah satu industri pangan. Salah satu industri kecil yang memproduksi kacang oven di KabupatenJember yang cukup produktif dan sustainable yakni hanya diproduksi oleh "UDRajawali" yang berlokasi kurang lebih 10 kilometer sebelum masuk kota Jember.Agroindustri "UD. Rajawali" merupakan industri kecil makanan ringan yang tetapbertahan dan berkembang sejak tahun 1998.
Sampai sekarang industri kecil ini sudahmampu memproduksi Kacang Oven rata-rata mengolah bahan baku kacang tanahsebanyak 3 ton $\mathbf{~ k g}$ per hari , kemudian menjadi kacang oven 1,45 ton dengan hargaRp 10.000 per kilogram. Wilayah pemasaran antara lain Kabupaten Jember,Banyuwangi, Bondowoso, dan Probolinggo, Kediri, Surabaya, dan Bali.Sampai sekarang dari volume produksi tersebut belum mampu memenuhipermintaan pasar, salah satu faktor utama diakibatkan proses produksi pengopenenanyang membutuhkan waktu cukup lama yaitu 2x24 jam setiap kali proses produksi.Pesaing utama produk kacang open yaitu kacang open yang diproduksi perusahaanbesar yang memiliki segmen pasar yang bebeda dan kontinuitas ketersediaan produk dipasar 
terjamin.Proses pembuatan Kacang Open "UD Rajawali" yang dilakukan meliputitahapan-tahapan proses pencucian, perebusan, penjemuran, pengopenan, penampian,dan pengemasan.

Proses pengopenan kacang yang dilakukan UKM mitra masihmenggunakan peralatan yang sangat sederhana yaitu sebuah rak anyaman keranjangbambu (model seperti drum) yang berdiameter 1 meter, tinggi 1,5 meter dan di bagiantengah berongga sebagai tempat memasukkan sumber panas yang menggunakan bahanbakar arang kayu. Kapasitas daya tampung masing-masing keranjang $50 \quad \mathrm{~kg}$ kacang.Selama proses pengopenan dilakukan pembalikan dua kali agar produk yang dihasilkanmendapatkan panas yang merata.

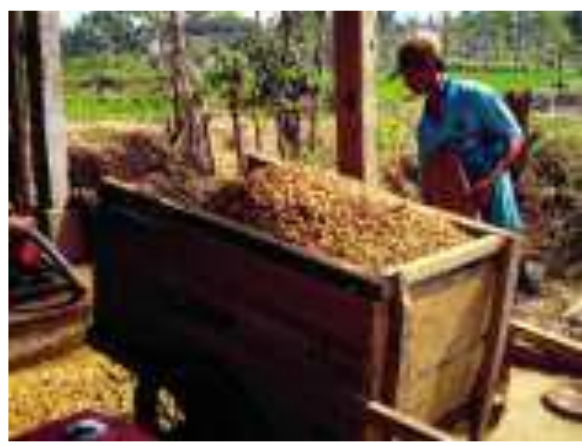

Gambar 1. Bahan Baku Kacang Tanah

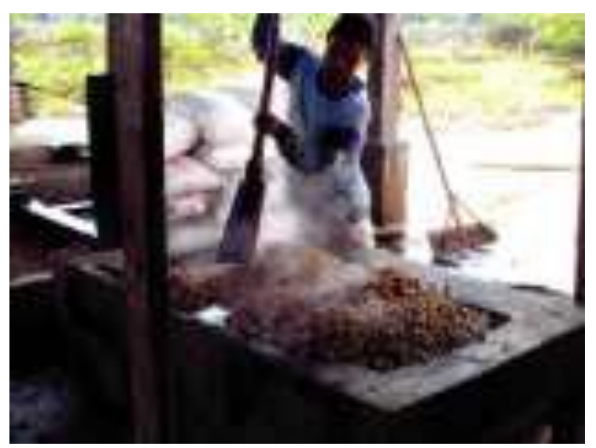

Gambar 2. Teknik Perebusan

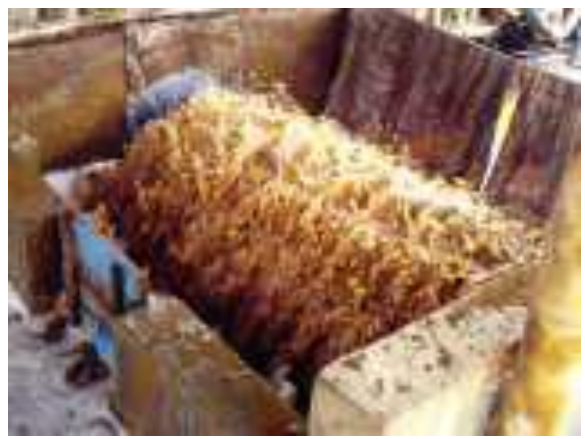

Gambar 3. Pencucian Secara Mekanis

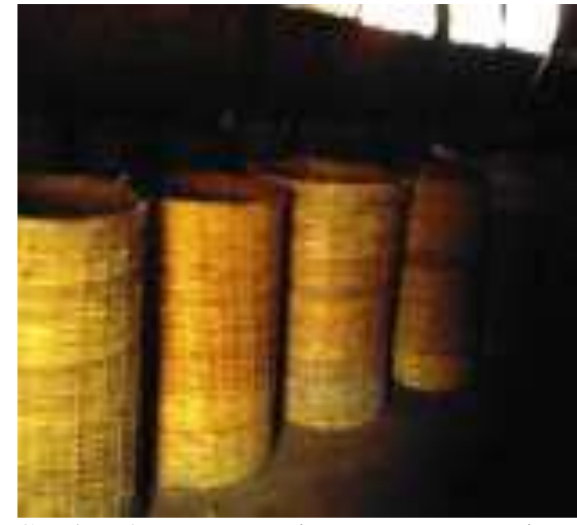

Gambar 4. Pengoperasian Dengan Keranjang

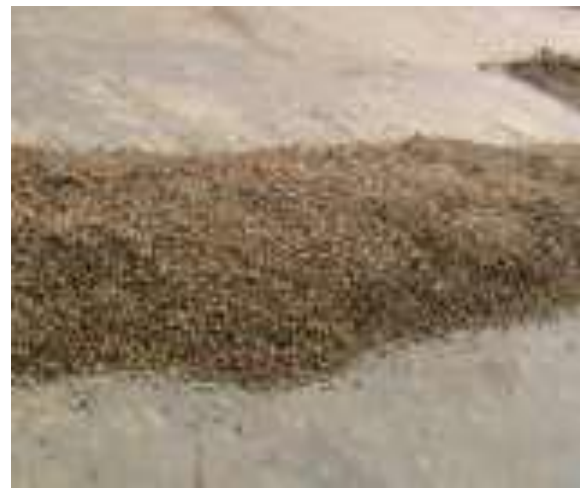

Gambar 5. Penjemuran Sinar Matahari
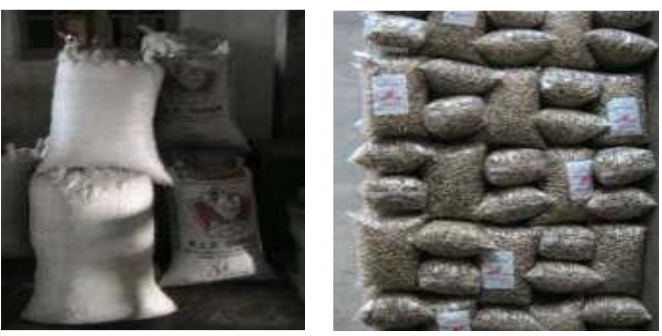

Gambar 6. Produk Siap Kirim Kemasan 2.5 kg Kacang Oven dan Kemasan Karung 20 kg

Kenyataan di lapangan menunjukkan bahwa UKM Mitra kesulitan dalampenyediaan bahan bakar arang kayu yang semakin mahal dan langka sehinggamengganggu kelancaran usaha dan menambah beban biaya produksi. Disamping itu,seiring dengan tuntuntan produksi bersih (cleaner production) maka tuntutanmengkonversi arang kayu ke gas LPG sudah menjadi kebutuhan yang sangat mendesakagar dihasilkan produk yang lebih berkualitas dan aman dikonsumsi serta berdampaknegatif terhadap lingkungan.Mengingat spesifikasi kualitas dan kuantitas akan permintaan produk yang terusmeningkat, maka perlu segera dilakukan peningkatan dari sisi teknologi prosesing danmanajemen, yakni:

a. Selama ini, proses pengeringan/pengoovenan hanya mengandalkan keranjangbambu berbahan bakar arang kayu,. Mengingat ketersediaan bahan bakar 
kayuarang yang semakin mahal maka perlu melakukan konversi bahan bakar ke gasLPG dan rekonstruksi Keranjang Dryer Oven.

b. Diperlukan perbaikan manajemen usaha khususnya administrasi keuangan diUKM Mitra.

Sampai saat ini manajemen usaha kususnya administrasi pembukuan UKM masih belum tertata dengan sistematis, sehingga masih memerlukan pembinaan dan pedampingan secara intensif agar mereka dapat melakukan pembukuan dengan baik

\section{BAB II. TARGET DAN LUARAN}

\subsection{Jenis Luaran yang Akan Dihasilkan}

1. Teknologi Dryer berbahan bakar gas LPG

2. Artikel Ilmiah

2.2 Target yang Ingin Dicapai

1. UKM memahami pentingnya penerapan teknologi produksi bersih

(cleaner production) dalam prosesing pengolahan kacang oven

2. Diterapkannya sistem drying berbahan bakar gas LPG

3. Peningkatan kualitas dan produktivitas minimal $10 \%$

4. Menurunkan biaya bahan bakar minimal 20\%

4. Perbaikan sistem manajemen administrasi keuangan di UKM Mitra

\section{BAB III. METODE PELAKSANAAN}

\subsection{Tahapan Solusi}

Kegiatan yang dilaksanakan dalam pengabdian kepada masyarakat ini meliputi 3 kegiatan utama yakni:

1. Koordinasi meliputi Observasi kebutuhan dan keinginan UKM Mitra

2. Penyusunan rencana kerja pelaksanaan kegiatan Pengabdian kepada Masyarakat

3. Melakukan kegiatan pelatihan tentang penerapan teknologi produksi bersih dalam produksi kacang oven yang bertujuan untuk meningkatkan pengetahuan dan pemahaman UKM Mitra pentingnya penerapan teknologi produksi bersih dalam produk kacang oven yang sehat dan berdampak kecil terhadap lingkungan.

4. Pembuatan dan pendampingan operasional penggunaan Dryer berbahan bakar gas LPG.

5. Pendampingan perbaikan manajemen administrasi keuangan UKM Mitra

3.2 Metode Yang Ditawarkan

a. Studi pustaka yakni mencari litaratur pendukung yang relevan

b. Identifikasi pemasalahan manajemen dan teknologi secara lebih detail guna adanya kesamaan persepsi antara kebutuhan UKM mitra kemampuan ilmiah dari perguruan tinggi

c. Pelatihan dan pendampingan Teknologi Produksi Bersih (Cleaner production) yang dilakukan Tim Pelaksana

d. Perancangan, pembuatan, dan aplikasi Dryer berbahan bakar Gas LPGkapasitas 50 kilogram di UKM Mitra

e. Evaluasi dan monitoring pelaksanaan program pengabdian kepada masyarakat

\section{HASIL DAN PEMBAHASAN}

Hasil dari kegiatan pengabdian kepada masyarakat yang diselenggarahan ini dalam rangka menjawab target dan luaran yang diharapkan dari kegiatan pengabdian yang dilaksanakan.

A. Teknologi Produksi Bersih

Produksi bersihadalah strategi pengelolaan lingkungan yang sifatnya mengarah pada pencegahan dan terpadu untuk diterapkan pada seluruh siklus produksi (UNIDO, 2002). Produksi bersih merupakan sebuah strategi pengelolaan lingkungan yang bersifat preventif atau pencegahan dan terpadu yang perlu diterapkan secara terus menerus pada proses produksi dan daur hidup produk dengan tujuan mengurangi risiko terhadap manusia dan lingkungan (UNEP, 2003). Hal tersebut, memiliki tujuan untuk meningkatkan produktivitas dengan memberikan tingkat efisiensi yang lebih baik pada penggunaan bahan mentah, energi dan air, mendorong performansi lingkungan yang lebih baik, melalui pengurangan sumber-sumber pembangkit limbah dan emisi serta mereduksi dampak produk terhadap lingkungan (UNIDO, 2002).

Beberapa kata kunci yang perlu dicermati dalam produksi bersih adalah pencegahan, terpadu, terus-menerus dan mengurangi risiko. Dalam strategi pengelolaan lingkungan melalui pendekatan produksi bersih, segela upaya dilakukan untuk mencegah atau menghindari terbentuknya limbah. Keterpaduan dalam konsep produksi bersih dicerminkan dari banyaknya aspek yang terlibat seperti sumber daya manusia, teknik teknologi, finansial, manajerial dan lingkungan. Strategi produksi bersih menekankan adanya upaya pengelolaan lingkungan secara terus-menerus. Suatu keberhasilan atau pencapaian target pengelolaan lingkungan bukan merupakan akhir suatu upaya melainkan menjadi input bagi siklus upaya pengelolaan lingkungan berikutnya. Mengurangi risiko dalam produksi bersih dimaksudkan dalam arti risiko keamanan, kesehatan, manusia dan lingkungan serta hilanganya sumber daya alam dan biaya perbaikan atau pemulihan (Indrasti, N.S. dan Fauzi, A.M. 2009). Produksi bersih diperlukan sebagai suatu strategi untuk mengharmonisasikan upaya perlindungan lingkungan dengan kegiatan pembangunan atau pertumbuhan ekonomi, mencegah terjadinya pencemaran lingkungan, memelihara dan 
memperkuat pertumbuhan ekonomi dalam jangka panjang, mencegah atau memperlambat terjadinya proses degradasi lingkungan dan pemanfaatan sumberdaya alam melalui penerapan daur ulang limbah serta memperkuat daya saing produk di pasar internasional (Indrasti, N.S. dan Fauzi, A.M. 2009)

Produksi bersih dapat dijadikan sebuah model pengeloaan lingkungan dengan mengedepankan efisiensi yang tinggi pada sebuah industri, sehingga timbulan/hasil limbah dari sumbernya dapat dicegah dan dikurangi. Penerapan produksi bersih akan menguntungkan industri karena dapat menekan biaya produksi, adanya penghematan, dan kinerja lingkungan menjadi lebih baik. Penerapan produksi bersih di suatu kawasan industri dapat digunakan sebagai pendekatan untuk mewujudkan Kawasan Industri Berwawasan Lingkungan (Purwanto, 2009).

Menurut Purwanto (2009) bahwa prinsipprinsip pokok dalam strategi produksi bersih adalah sebagai berikut:

1. Mengurangi dan meminimisasi penggunaan bahan baku, air dan pemakaianbahan baku beracun dan berbahaya serta mereduksi terbentuknya limbah pada sumbernya sehingga mencegah dan atau mengurangi timbulnya masalah pencemaran dan kerusakan lingkungan serta resikonya terhadap manusia. 2. Perubahan dalam pola produksi dan konsumsi, berlaku balk pada proses maupun produk yang dihasilkan, sehingga harus dipahami betul analisis daur hidup produk.

3. Upaya produksi bersih ini tidak akan berhasil dilaksanakan tanpa adanya perubahan dalam pola pikir, sikap dan tingkah laku dari semua pihak terkait baikpemerintah, masyarakat maupun kalangan dunia usaha. Selain itu pula perlu diterapkan pola manajemen di kalangan industri maupun pemerintah yang telah mempertimbangkan aspek lingkungan. 8

4. Mengaplikasikan teknologi akrab lingkungan, manajemen dan prosedur standar operasi sesuai dengan persyaratan yang ditetapkan. Kegiatankegiatan tersebut tidak selalu membutuhkan biaya investasi yang tinggi, kalaupun terjadi seringkali waktu yang diperlukan untuk pengembalian modal investasi relative singkat

5. Pelaksanaan program produksi bersih ini lebih mengarah pada pengaturan diri sendiri (self regulation) dari pada pengaturan secara command and control. Jadi pelaksanaan program produksi bersih ini tidak hanya mengandalkan peraturan pemerintah saja, tetapi lebih didasarkan kesadaran utuk merubah sikap dan tingkah laku.

Prinsip-prinsip dalam produksi bersih diaplikasikan dalam bentuk kegiatan yang dikenal sebagai 4R, meliputi:
1. Reuse, atau penggunaan kembali adalah suatu teknologi yang memungkinkan suatu limba dapat digunakan kembali tanpa mengalami perlakukan fisika/kimia/biologi.

2. Reduction, atau pengurangan limbah pada sumbernya adalah teknologi yang dapat mengurangi atau mencegah timbulnya pencemaran di awal produksi misalnya substitusi bahan baku yang ber B3 dengan B9 segregasi tiada.

3. Recovery, adalah teknologi untuk memisahkan suatu bahan atau energi dari suatu limbah untuk kemudian dikembalikan ke dalam proses produksi dengan atau tanpa perlakuan fisika/kimia/biologi.

4. Recycling, atau daur ulang adalah teknologi yang berfungsi untuk memanfaatkan limbah dengan memprosesnya kembali ke proses semula yang dapat dicapai melalui perlakuan fisika/kimia/biologi.

Prinsip 4R yang saat ini telah dikembangkan, aplikasikasinya akan lebih efektif apabila didahului dengan prinsipRethink. Prinsip ini adalah suatu konsep pemikiran yang harus dimiliki pada saat awal kegiatan akan beroperasi.

Dalam kegiatan Pengabdian kepada masyarakat ini ada beberapa tahapan yang harus dilakukan meliputi : Koordinasi dengan Mitra, Perencanaan Kegiatan, Sosialisasi/ Pelatihan penggunaan Teknologi Dryer, Perancangan, pembuatan, dan aplikasi Dryer berbahan bakar Gas LPG kapasitas 50 kilogram dan Evaluasi.

1. Koordinasi dengan Mitra

Dalam melakukan koordinasi dengan mitra Tim melakukan identifikasi, diskusi, menerima masukan masukan dan saran, hal ini dilakukan dengan harapan bahwa kegiatan pengabdian yang akan diterapkan betul betul sesuai dengan kebutuhan dan keinginan mitra serta sesuai dengan ketrampilan yang dimiliki oleh mitra sehingga dapat meningkatkan pendapatan mitra. Disamping itu agar nantinya kegiatan pengabdian ini tidak sia sia dan tidak berfungsi sesuai dengan tujuan pengabdian kepada masyarakat.

\section{Perencanaan dan Sosialisasi}

Dalam kegiatan pengabdian ini diperlukan perencanaan yang tepat sesuai dengan ketersediaan bahan, waktu dan tenaga kerja. Persoalan utama yang dihadapi mitra yang dijadikan tempat pengabdian salah satu faktor utama diakibatkan proses produksi pengopenenan yang membutuhkan waktu cukup lama yaitu 2x24 jamsetiap kali proses produksi.

Pesaing utama produk kacang open yaitu kacang open yang diproduksi perusahaan besar yang memiliki segmen pasar yang bebeda dan kontinuitas ketersediaan produk di pasar terjamin. Oleh karena itu diperlukan perencanaan dan sosialisasi yang 
intensif dalam merencanakan alat yang akan dipakai untuk proses produksi kacang oven.

3. Perancangan, pembuatan, dan aplikasi Dryer berbahan bakar Gas LPG kapasitas 50 kilogram.

Teknologi Dryer Berbahan bakar Gas LPG dengan kapasistas $50 \mathrm{Kg}$, berfungsi untuk menghasilkan proses produksi bersih dapat dijadikan sebuah model pengeloaan lingkungan dengan mengedepankan efisiensi yang tinggi pada sebuah industri, sehingga timbulan/hasil limbah dari sumbernya dapat dicegah dan dikurangi. Penerapan produksi bersih akan menguntungkan industri karena dapat menekan biaya produksi, adanya penghematan, dan kinerja lingkungan menjadi lebih baik. Penerapan produksi bersih di suatu kawasan industri dapat digunakan sebagai pendekatan untuk mewujudkan Kawasan Industri Berwawasan Lingkungan (Purwanto, 2009).

Adapun hasil kegiatan pengabdian pada UKM Nampak dalam foto kegiatan.

\section{B. Teknologi Dryer Berbahan Bakar Gas LPG}

\section{DRYER KACANG OVEN}
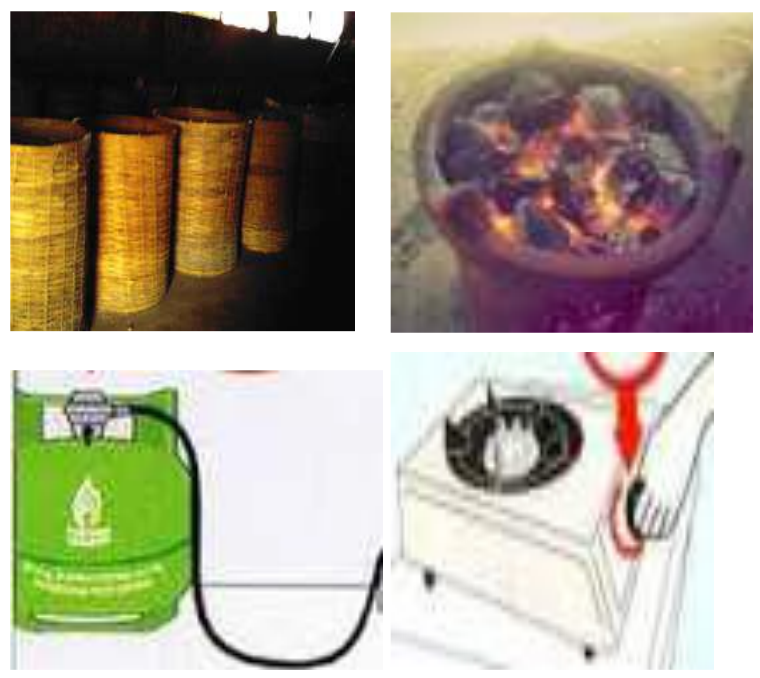

Gambar 7.

\section{BERBAHAN BAKAR ARANG KAYU BERBAHAN BAKAR GAS LPG}

\begin{tabular}{|c|c|}
\hline $\begin{array}{l}\text { Kelebihan: } \\
\text { 1. dapat diperoleh } \\
\text { secara lokal } \\
2 . \quad \text { tidak butuh } \\
\text { investasi peralatan }\end{array}$ & $\begin{array}{l}\text { Kelebihan: } \\
\text { 1. Hemat Waktu } \\
\text { 2. Praktis dan cepat } \\
\text { 3. Lebih Higienis } \\
\text { 4. Tidak berbau } \\
\text { terhadap produk dab } \\
\quad \text { ruangan kerja } \\
\text { 5. Lebih irit/efisien } \\
\text { 6. Ramah lingkungan } \\
\text { 7. Mudah isi ulang } \\
\text { 8. Menghemat anggaran } \\
\text { negara untuk }\end{array}$ \\
\hline
\end{tabular}

\begin{tabular}{|c|c|}
\hline & BBM \\
\hline $\begin{array}{l}\text { Kekurangan } \\
\text { 1. Berbau dan Berasap } \\
\text { 2. Tidak praktis } \\
\text { 3. Harga yang tidak } \\
\text { menentu } \\
\text { 4. Efisiensi rendah } \\
\text { 5. Terbatas diperoleh } \\
\text { di wilayah } \\
\text { pedesaan } \\
\text { 6. Butuh ruang } \\
\text { pembakaran dan stok } \\
\text { gudang yang besar } \\
\text { 7. Produk yang } \\
\text { dihasilkan berbau asap } \\
\text { Arang }\end{array}$ & $\begin{array}{l}\text { Kekurangan: } \\
\text { 1. Dibutuhkan } \\
\text { kemampuan untuk } \\
\quad \text { keamanan } \\
\text { 2. Ketergantungan } \\
\text { terhadap pasokan dari } \\
\quad \text { distributor } \\
\text { 3. Membutuhkan } \\
\text { investasi peralatan }\end{array}$ \\
\hline
\end{tabular}

\section{BAB V. KESIMPULAN}

Berdasarkan hasil kegiatan yang telah dilaksanakan maka dapat disimpulkan bahwa :

1. Koordinasi senantiasa dilakukan dengan mitra sehingga terjalin hubungan yang lebih baik

2. Sosialisasi dan identifikasi kebutuhan dan permasalahan telah dilaksanakan dengan baik dan lancar dengan mitra.

3. Pelatihan dan Perancangan penggunaan teknologi dryer berbahan bakar Gas LPG telah dilaksanakan dengan baik dan mitra sangat antusias dalam mengikuti kegiatan pelatihan dan perencangan teknologi tersebut

4. Praktek penggunaan Teknologi Dryer Oven Kacang telah dilaksanakan sesuai dengan rencana dan mampu diaplikasikan sehingga dapat membantu menciptakan proses produksi kacang over secara baik dan lancar

Saran

1. Diharapkan kegiatan pengabdian kepada masyarakat perlu ditingkatkan intensitasnya.

2. Diharapkan kegiatan pengabdian kepada masysrakat diperluas sasaran yang memperoleh kegiatan semacam ini.

\section{DAFTAR PUSTAKA}

[1]. Anonim. 2007. Pengelolaan Limbah Industri Pangan. Direktorat Jenderal Industri Kecil Menengah. Departemen Perindustrian. Jakarta.

[2]. Djamali, R. A. 2001. Panduan Wirausaha Agroindustri Kacang Oven. Dinas Petrindustrian dan Perdagangan Propinsi Jawa Timur.

[3]. Indrasti, N.S. dan Fauzi, A.M. 2009. Produksi Bersih. IPB Press. Bogor.

[4]. Purwanto. 2009. Penerapan Produksi Bersih di untuk Meningkatkan Efisiensi dan

Mencegah Pencemaran Industri Orasi Ilmiah yang Disampaikan dalam Upacara Penerimaan Guru Besar dalam Ilmu Teknik Kimia Fakultas Teknik Universitas Diponegoro. Badan Penerbit $\begin{array}{lll}\text { Universitas } & \text { Diponegoro. }\end{array}$ 
[5]. UNIDO. 2002. What is Cleaner Production. Di dalam http://www.unido.org/doc/5151.

[6]. UNEP.2003. Cleaner Production Assesment in Industries. Di dalam http://www.uneptie.org/pc/cp/understanding_cp/cp industries. htm.

\section{Lampiran : FOTO KEGIATAN}
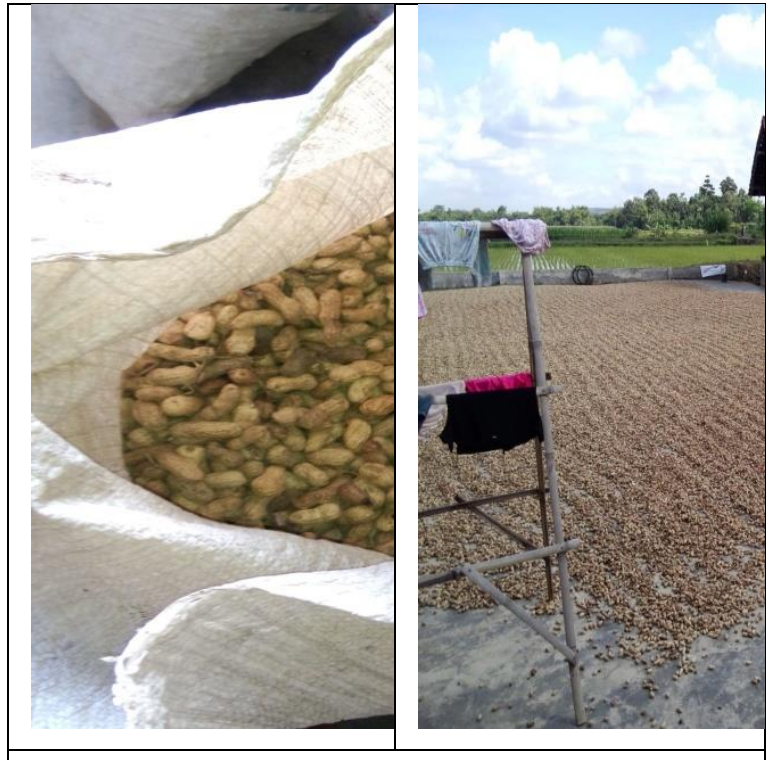

Bahan Baku Kacang Oven

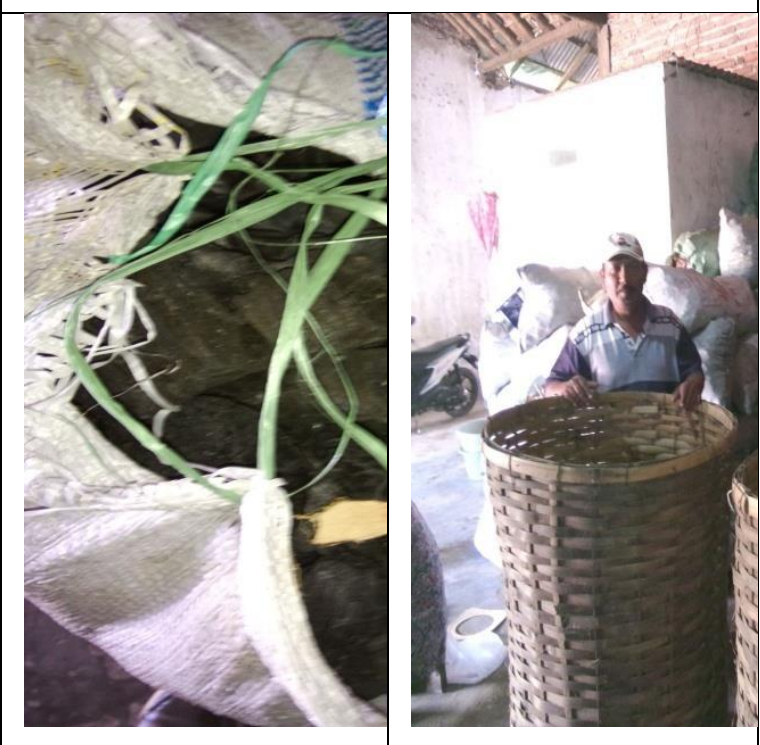

Keranjang Oven Kacang

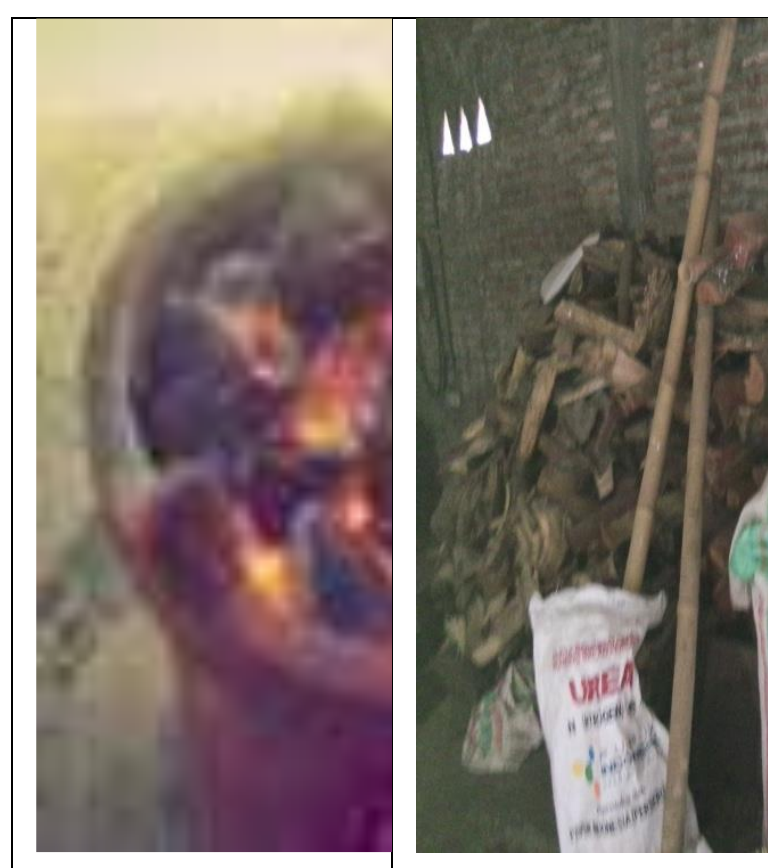

Oven Kacang dengan menggunakan Tungku ( Tradisional )
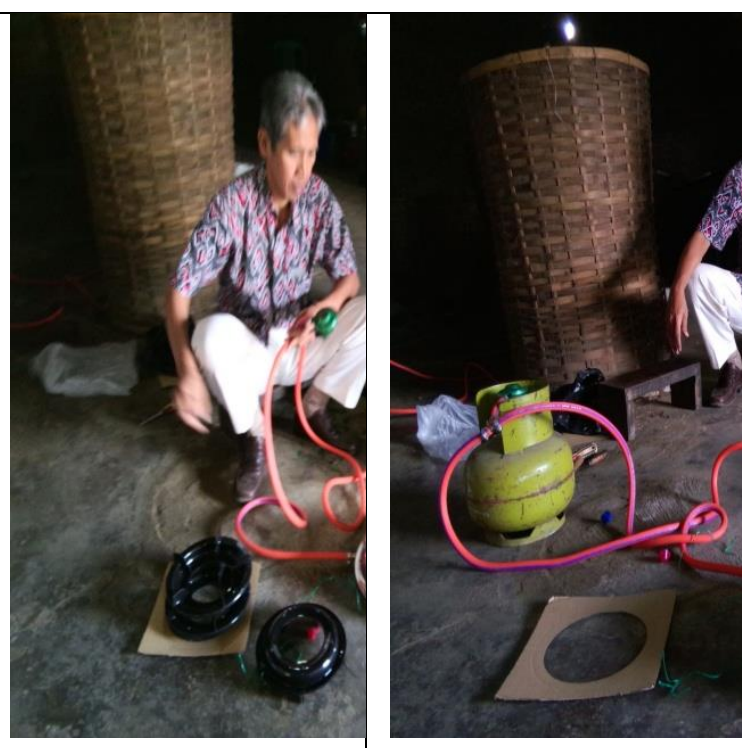

Teknologi Dryer Oven Berbahan Bakar Gas LPG 


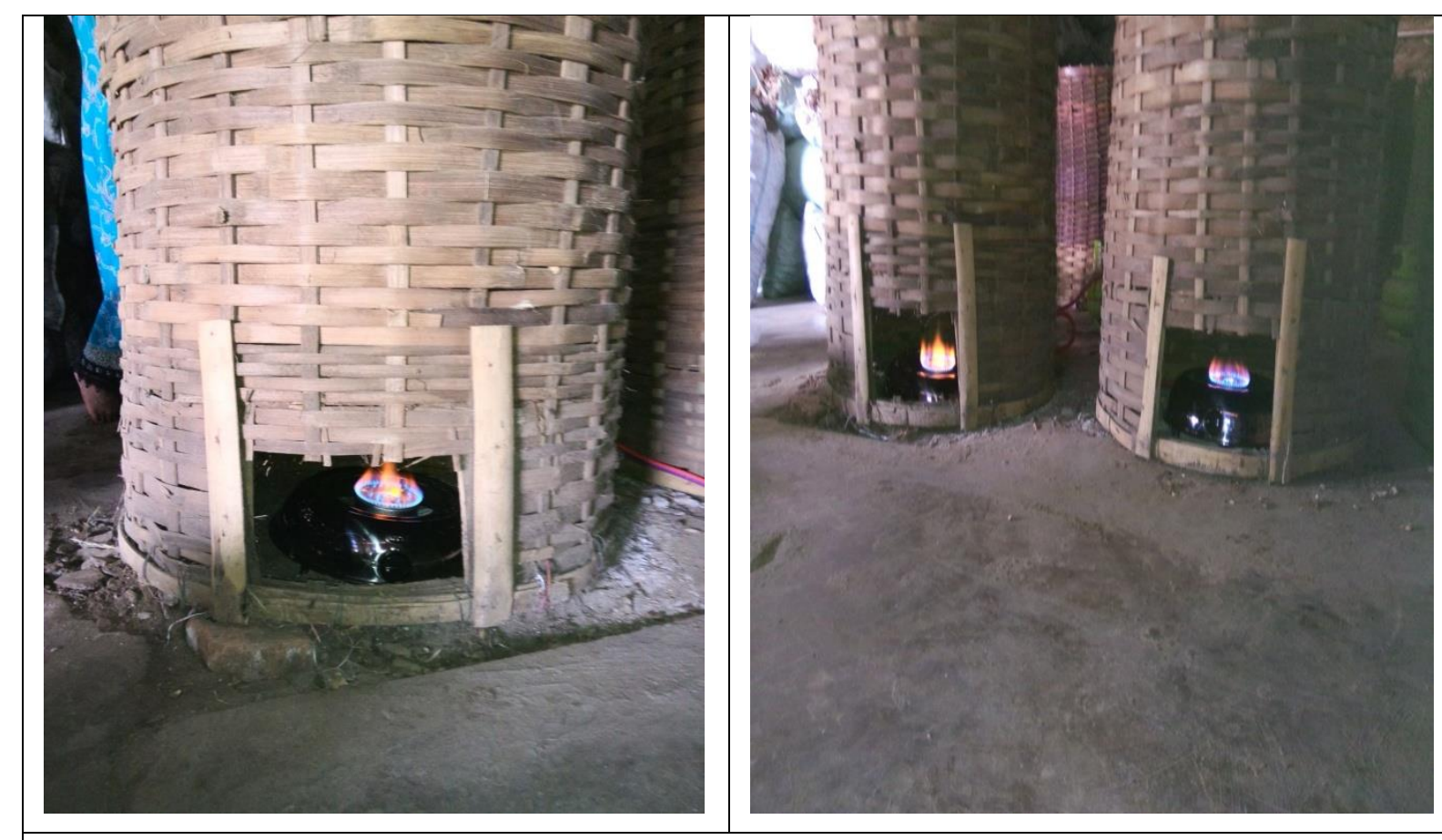

Hasil kegiatan Pengabdian pada UKM Kacang Over "RAJAWALI “ Jember

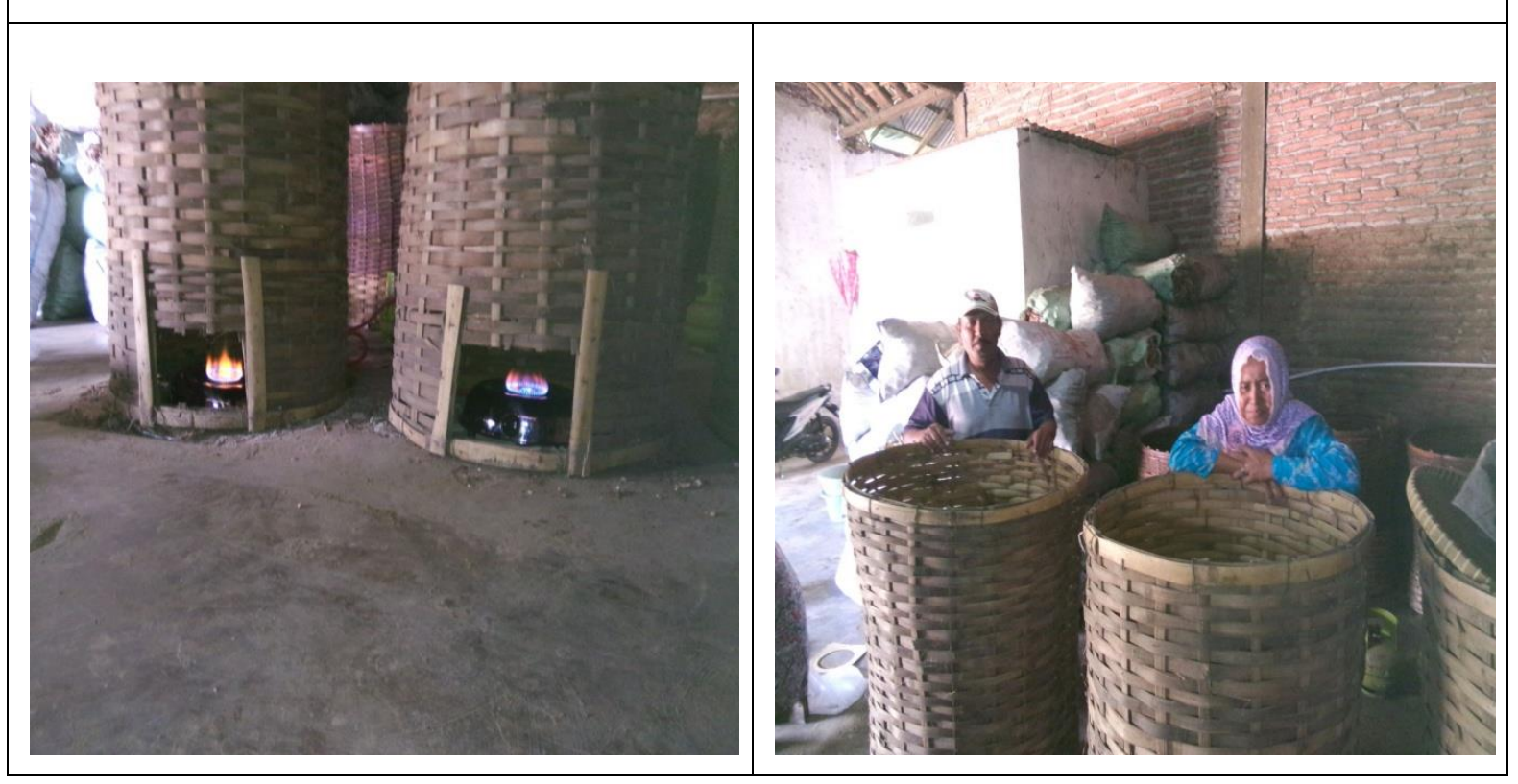

